\title{
RHEOLOGICAL BEHAVIOUR AND IN VITRO RELEASE PROFILES OF NAFTIFINE TOPICAL HYDROGELS
}

\author{
OANA KARAMPELAS \#, TEODORA DALILA BALACI ${ }^{\text {, }}$ CRISTIAN FUNIERU ${ }^{\#}$, EMMA \\ ADRIANA OZON *, MIRELA ADRIANA MITU, CĂTĂLINA ANCUȚA FIȚA, DUMITRU \\ LUPULIASA
}

“Carol Davila” University of Medicine and Pharmacy Bucharest, Romania

*corresponding author: emmacretu@yahoo.com

${ }^{\#}$ Authors with equal contribution.

Manuscript received: February 2020

\begin{abstract}
The study is presenting the formulation and manufacturing process of 15 hydrogels formed by different cellulose derivative containing 1\% naftifine hydrochloride dissolved in a mixture of cosolvents with low amounts of alcoholic components. The obtained products were evaluated by modelling their flow behaviour and by studying the in vitro release profile in vertical diffusion cell systems. The formulations showed a typical pseudoplastic behaviour. The range of variation in diffusion coefficient values is remarkably low, compared to structural differences easily detectable and demonstrated by rheological behaviour analysis. The increase in the concentration of the cellulose derivative matrix former leads to proportional decreases in diffusion coefficient values for naftifine, correlated with structural parameters.
\end{abstract}

\section{Rezumat}

Studiul prezintă formularea și prepararea a 15 hidrogeluri generate de diferiți derivați de celuloză, conținând 1\% clorhidrat de naftifină dizolvat într-un amestec de cosolvenți cu un conținut scăzut de componente alcoolice. Produsele obținute au fost evaluate prin modelarea comportamentului lor de curgere și prin studierea profilului de eliberare in vitro în sistemele celulare verticale de difuzie. Formulările au prezentat un comportament pseudoplastic tipic. Intervalul de variație a valorilor coeficientului de difuzie este foarte scăzut, comparativ cu diferențele structurale ușor detectabile și demonstrate prin analiza comportamentului reologic. Creșterea concentrației derivatului de celuloză duce la scăderea proporțională a valorilor coeficientului de difuzie pentru naftifină, corelată cu parametrii structurali.

Keywords: naftifine hydrochloride, cellulose derivative gels, rheological behaviour, in vitro release profiles

\section{Introduction}

Naftifine hydrochloride $(\mathrm{N})$ is a broad-spectrum antifungal agent, used in topical products due to its effectiveness and safety properties [2]. The marketed pharmaceutical products are characterized either by their high content of volatile alcoholic components as cosolvents, either by the lipophilic nature of the vehicle, both of which have associated bioavailability problems. For hydroalcoholic solutions, in vivo studies indicate an alteration over time of the active ingredient thermodynamic activity, a direct effect of the solubilisation agents loss [6, 16, 19]. Oversaturated systems are generated in situ, which induce a maximum transfer speeds through the corneal layer, on quite short time intervals. At the same time, depending on the active ingredient solubility profile and on the functional status of the membrane interface, the transfer of liposoluble substances may be limited by the distribution coefficient values $[8,9,17]$. Consequently, the selection of the pharmaceutical vehicle requires the establishment of a compromise between the characteristics imposed by the physico-chemical properties of the active ingredient and those demanded by the biological barrier [7, 10, 18].

Recently, different studies reported that naftifine hydrochloride inclusion in cyclodextrins [1] or in niosomes [22] are viable alternatives for high concentrations of alcoholic components.

It is considered that the assessment of the in vitro release profile, through the selection of experimental variables and the validation of the discriminatory character against different levels of compositional or process changes, may provide relevant information on the in vivo pharmaceutical product performances $[11,13,20]$. The transfer rate from the pharmaceutical form is the result of both active ingredient physicochemical properties and vehicle structure, by the diffusional resistance it imposes [9, 12]. The contribution of this last factor can be estimated by the rheological behaviour study. Modelling of the rheological profile can provide the quantitative parameters necessary for the evaluation of correlations used a selection of criteria in the research and development process [14, 15, 21, 23]. 
FARMACIA, 2020, Vol. 68, 6

In the present study, we developed fifteen gel formulations containing $1 \%$ concentration of naftifine hydrochloride solubilized in semisolid matrix with obvious structural differences, induced by various concentrations and combinations of hydrophilic macromolecular agents. The gels were evaluated by modelling their flow behaviour and by studying the in vitro release profile in vertical diffusion cell systems. Finally, the correlation of structural and diffusional characteristics, was performed, highlighting the influence of formulation factors (nature and concentration of matrix forming macromolecular compounds, absorption promoters or solubility agents).

\section{Materials and Methods}

Naftifine hydrochloride (1\%) was included into the hydrophile matrix of different cellulose derivatives as solutions in cosolvent systems, including absolute ethanol and at least one absorption promoter. Also, naftifine hydrochloride was added to polyethylene glycols dispersions (PEG 200 or 400 and PEG 4000, 40:60, g:g), containing $10 \%$ absolute ethanol or mixture of equal volumes of absolute ethanol and isopropanol. The development of these formulations aimed at assessing the in vitro release behaviour of anhydrous matrices.

\section{Materials}

The following materials were used in the present study: naftifine hydrochloride, Sifavitor SRL, Italy; Fancol ${ }^{\circledR}$ Iso, (isopropyl myristate, lanolin, oleyl alcohol), HSH Chemie, Germany; Cremophor ${ }^{\circledR}$ EL, (PEG-35 Castor oil, polyoxyl 35 Castor oil), BASF, Germany; methylcellulose, Ph Eur viscosity: 5140 mPa.s, Fluka/Sigma Chemie GmbH, USA; hydroxyethyl-cellulose BioChemika, Fluka Analytical, Germany; hydroxypropylmethyl cellulose, BioChemika, Fluka Analytical, Japan; triethanolamin > 99\%, Carl Roth $\mathrm{GmbH}+\mathrm{Co}$. KG, Germany; polyethylene glycol 200, Sigma Aldrich, USA; ethanol absolute, Chromasolv, Sigma Aldrich, USA; 2-propanol Rotisolv ${ }^{\circledR}$ HPLC, Carl Roth $\mathrm{GmbH}+\mathrm{Co} . \mathrm{KG}$, Germany; isopropyl myristate, Scharlau Chemie S.A., Spain; purified water generated by a SGW Ultraclear UV PlusTM system, Germany. Methods

The formulations of hydrophilic gels are presented in Table I. Each formulation is further identified by the abbreviated name of the cellulose derivative, followed by its percent concentration.

Table I

The formulation of the hydrophilic gels

\begin{tabular}{|c|l|c|c|c|c|c|c|c|c|c|}
\hline \multicolumn{9}{|c|}{ Ingredient (g/100 g) } \\
\hline No & Formulation Code & N & HPMC & MC & HEC & EtOH & PEG 200 & Iso & CreEL & $\mathbf{H}_{2} \mathbf{O}$ \\
\hline 1 & N-HPMC 1\% & 1 & 1 & - & - & 10 & 5 & 5 & 1 & 77 \\
\hline 2 & N-HPMC 2\% & 1 & 2 & - & - & 10 & 5 & 5 & 1 & 76 \\
\hline 3 & N-HPMC 3\% & 1 & 3 & - & - & 10 & 5 & 5 & 1 & 75 \\
\hline 4 & N-HPMC 4\% & 1 & 4 & - & - & 10 & 5 & 5 & 1 & 74 \\
\hline 5 & N-MC 1\% & 1 & - & 1 & - & 10 & 5 & 5 & 1 & 77 \\
\hline 6 & N-MC 2\% & 1 & - & 2 & - & 10 & 5 & 5 & 1 & 76 \\
\hline 7 & N-MC 3\% & 1 & - & 3 & - & 10 & 5 & 5 & 1 & 75 \\
\hline 8 & N-MC 4\% & 1 & - & 4 & - & 10 & 5 & 5 & 1 & 74 \\
\hline 9 & N-HEC 1\% & 1 & - & - & 1 & 10 & 5 & 5 & 1 & 77 \\
\hline 10 & N-HEC 2\% & 1 & - & - & 2 & 10 & 5 & 5 & 1 & 76 \\
\hline 11 & N-HEC 3\% & 1 & - & - & 3 & 10 & 5 & 5 & 1 & 75 \\
\hline 12 & N-HEC 4\% & 1 & - & - & 4 & 10 & 5 & 5 & 1 & 74 \\
\hline 13 & N-HPMC - MC 1\% & 1 & 1 & 1 & - & 10 & 5 & 5 & 1 & 76 \\
\hline 14 & N-HPMC - HEC 1\% & 1 & 1 & - & 1 & 10 & 5 & 5 & 1 & 76 \\
\hline 15 & N-HEC - MC 1\% & 1 & - & 1 & 1 & 10 & 5 & 5 & 1 & 76 \\
\hline
\end{tabular}

$\mathrm{N}$ - naftifine hydrochloride (N), HPMC - hydroxypropyl-methyl cellulose, MC- methyl cellulose, HEC -hydroxyethyl-cellulose, EtOH ethanol absolute, PEG 200 - polyethylene glycol 200, Iso - isopropanol, CrEL - Cremophor® EL (PEG-35 Castor oil), $\mathrm{H}_{2} \mathrm{O}$ - purified water

The raw materials were weighed using a Semi Micro Analytical balance (Radwag XA 210/X, Radwag Wagi Elektroniczne, with $0.01 \mathrm{mg}$ accuracy). The gel matrices were prepared by separate hydration (with $70 \%$ of the water quantity available in the formula) for 48 hours at $2-8^{\circ} \mathrm{C}$. The cosolvent systems including the active ingredient were dispersed in the hydrated gels and homogenized for 10 minutes at 10,000 rpm, using a Heidolph RZR 2020 mechanical stirrer, Germany. The structural and drug release evaluations were performed after at least 24 hours of storage at room temperature.
The rheological behaviour of the gels was performed on a rotational viscometer Rheometer type $\mathrm{RC} 1$, RheoTec $\mathrm{GmbH}$, Germany, with $\mathrm{CCl}_{4}$ coaxial cylinder (share rate values interval: $0-150 \mathrm{~s}^{-1}$, on ascending and descending routes, at $25^{\circ} \mathrm{C}$; volume: $3 \mathrm{~mL}$ ). Rheo 3000 software, vers. 1.2.1328.1, RheoTec Messtechnik $\mathrm{GmbH}$ - Brookfield Engineering Labs., Inc. was used for primary recording, data processing (including basic statistics and thixotropy area) and flow profile modelling (Ostwald de Waele model).

The procedure used to determine the in vitro drug release was already described by Manescu $\mathrm{O}$ et al. 
in detail [4]. Briefly, a Hanson Microette system (Hanson Research Inc., USA) of $12 \mathrm{~mL}$ vertical diffusion cells (useful volume of $10 \mathrm{~mL}$ ), with $30 \%$ ethanol absolute in purified water as receptor media, was used. Approximately $300 \mathrm{mg}$ of each formulation was applied on polysufone membranes (Tuffryn ${ }^{\circledR}$, PALL Life Sciences HT-450, $0.45 \mu \mathrm{m}$ average pore size, batch no. T72556), with $0.5 \mathrm{~mL}$ samples collected at 15, 30, 60, 90, 120, 150 and 180 minutes after application. The tests were performed in triplicate, at $32 \pm 0.5^{\circ} \mathrm{C}$ and at $400 \mathrm{rpm}$ stirring rate [5].

Quantitative evaluation of naftifine hydrochloride in the samples was carried out by a spectrophotometric method, on a Jasco UV-Vis V-530 spectrophotometer (equipped with Spectra Manager software for Windows 95/NT, version 1.54.03), at $252.8 \mathrm{~nm}$. Exoderil ${ }^{\circledR}$ Cream, Exoderil ${ }^{\circledR}$ Solution and Naftifina Antibiotice Cream were evaluated and used as reference products, and their in vitro drug release profiles were already published [4].

\section{Results and Discussion}

The rheological behaviour of the obtained gels

Naftifine hydrogels viscosity data analysis are represented as the variation of viscosity with shear rate, as well as variation of shear stress according to viscosity, as it can be seen in the Figures $1-15$.
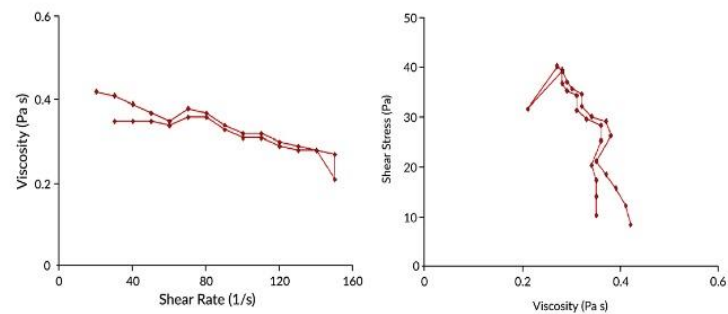

Figure 1.

The variation of viscosity with shear rate. Flowability curve, the variation of shear stress according to viscosity - Formulation: N-MC $1 \%$
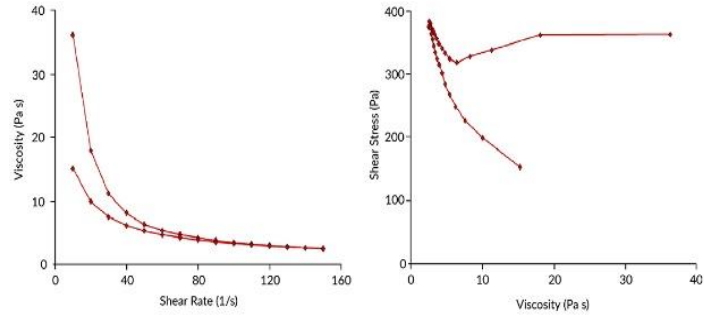

Figure 3.

The variation of viscosity with shear rate. Flowability curve, the variation of shear stress according to viscosity - Formulation: N-MC 3\%
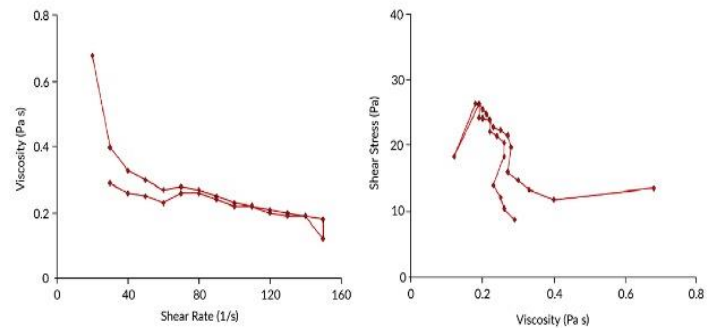

Figure 5.

The variation of viscosity with shear rate. Flowability curve, the variation of shear stress according to viscosity - Formulation: N-HEC $1 \%$
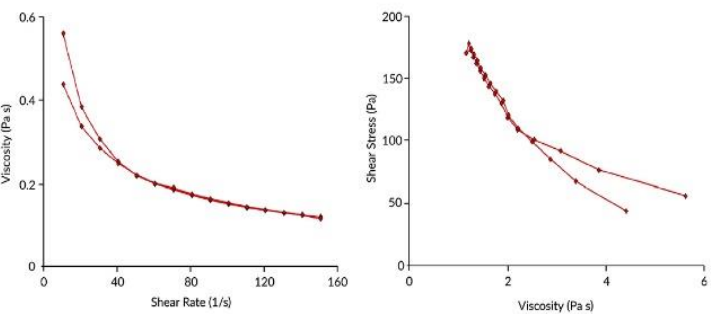

Figure 2.

The variation of viscosity with shear rate. Flowability curve, the variation of shear stress according to viscosity - Formulation: N-MC $2 \%$
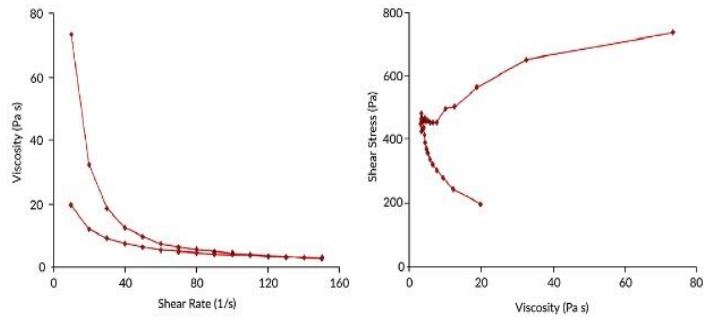

Figure 4.

The variation of viscosity with shear rate. Flowability curve, the variation of shear stress according to viscosity - Formulation: N-MC 4\%
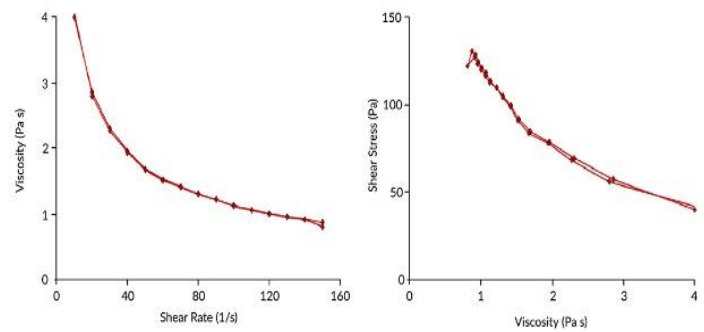

Figure 6.

The variation of viscosity with shear rate. Flowability curve, the variation of shear stress according to viscosity - Formulation: N-HEC 2\% 


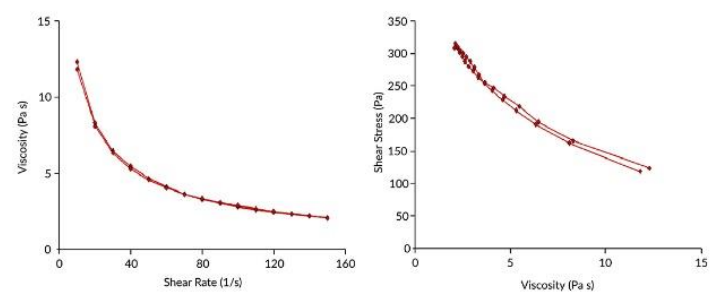

Figure 7.

The variation of viscosity with shear rate. Flowability curve, the variation of shear stress according to viscosity - Formulation: N-HEC 3\%
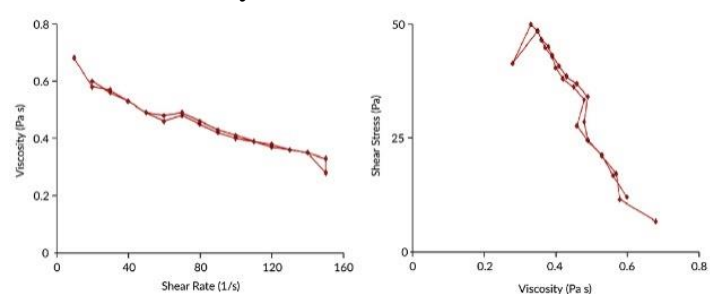

Figure 9.

The variation of viscosity with shear rate. Flowability curve, the variation of shear stress according to viscosity - Formulation: N-HPMC $1 \%$
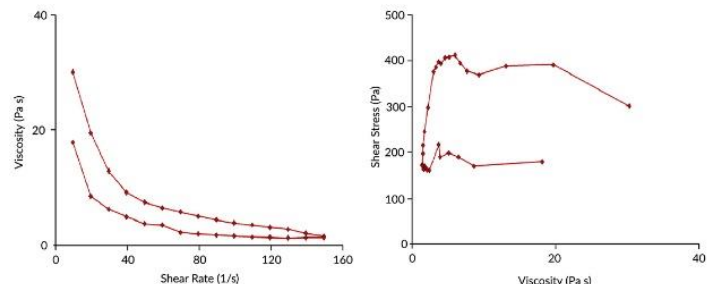

Figure 11.

The variation of viscosity with shear rate. Flowability curve, the variation of shear stress according to viscosity - Formulation: N-HPMC 3\%
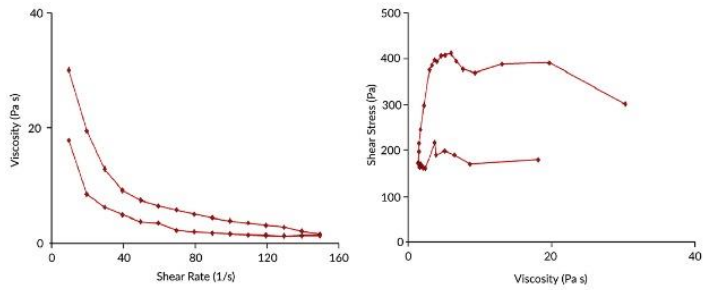

Figure 13.

The variation of viscosity with shear rate. Flowability curve, the variation of shear stress according to viscosity - Formulation: N-HPMC-MC 1\%

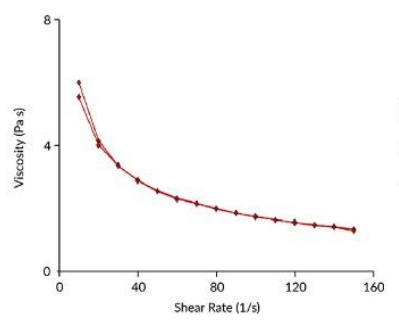

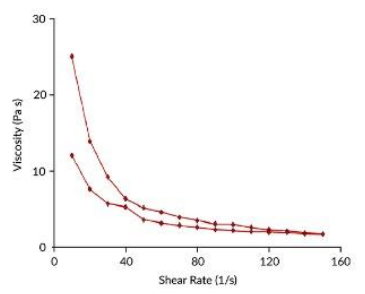

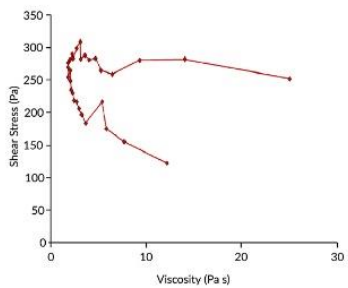

Figure 8.

The variation of viscosity with shear rate. Flowability curve, the variation of shear stress according to viscosity - Formulation: N-HEC 4\%
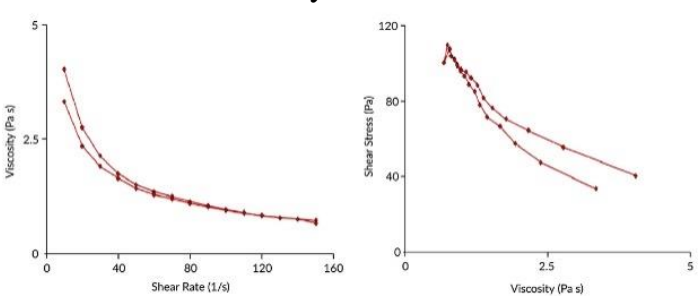

Figure 10.

The variation of viscosity with shear rate. Flowability curve, the variation of shear stress according to viscosity - Formulation: N-HPMC 2\%
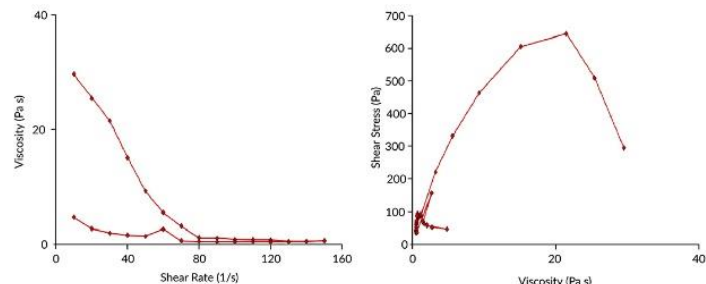

Figure 12.

The variation of viscosity with shear rate. Flowability curve, the variation of shear stress according to viscosity - Formulation: N-HPMC 4\%
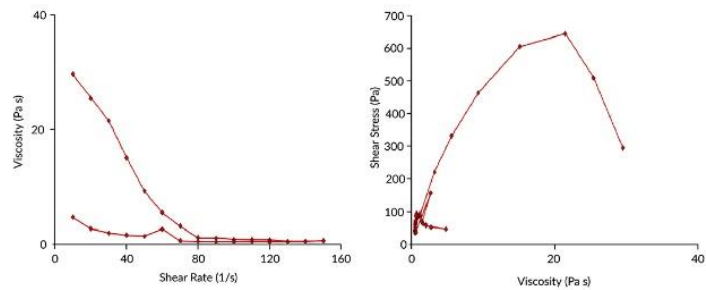

Figure 14.

The variation of viscosity with shear rate. Flowability curve, the variation of shear stress according to viscosity - Formulation: N-HPMC-HEC 1\%

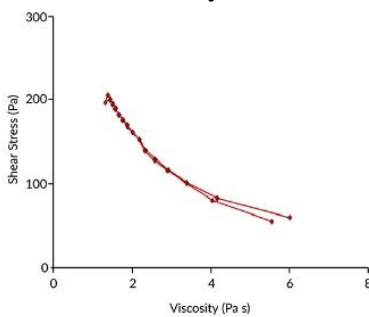

Figure 15.

The variation of viscosity with shear rate. Flowability curve, the variation of shear stress according to viscosity - Formulation: N-HEC-MC $1 \%$ 
All studied products show a pseudoplastic flow behaviour typical for hydrophilic gels, with the viscosity values decreasing with the increase of shear rate. For most of the formulation we can remark the hysteresis curve presence, the descending path being below the ascending one. [24, 25] There are few exceptions, cases where the two routes are practically overlapping: $1 \%$ and $2 \% \mathrm{MC}, 1 \%$ and $2 \% \mathrm{HEC}$, $1 \% \mathrm{HPMC}$ and $1 \% \mathrm{MC}-\mathrm{HEC}$. It is significant that the presence of high concentrations of matrix forming agents, i.e. $3 \%$ and $4 \%$ in case of $\mathrm{MC}$ and $\mathrm{HEC}$, and $2-4 \%$ in case of HPMC, led to the obtaining of thixotropic hydrogels. [3] A similar behaviour is noticed also when HPMC was associated with MC or HEC, even at low concentration of $1 \%$.

Structural and conformational changes in cellulose derivatives matrix formers, alone or in combinations, have also been assessed with the help of thixotropy analysis, as can be seen from Figure 16.

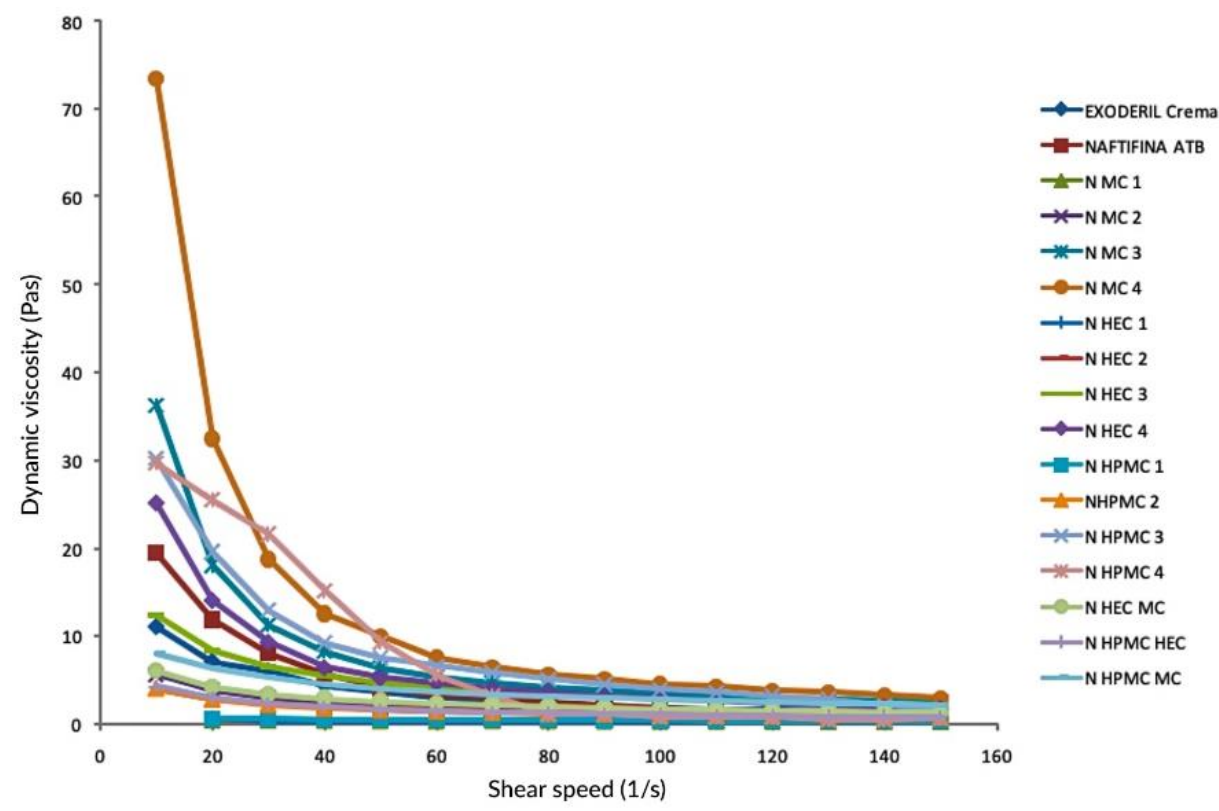

Figure 16.

The rheological behaviour analysis of naftifine hydrochloride formulations

It is remarkable the wide range of variation of hysteresis areas, from about $71 \mathrm{~Pa} / \mathrm{s}$ for N-MC $1 \%$ to approximately $27,000 \mathrm{~Pa} / \mathrm{s}$ for N-HPMC $3 \%$ and N-HPMC 4\%. For Naftifina AB, Exoderil cream and N-MC 4\%, N-HEC 4\%, N-MC 3\% hydrogels, thixotropy area registered values between 5000 and $20000 \mathrm{~Pa} / \mathrm{s}$, representing well-structured matrices in terms of thixotropy.

For the hydrogels obtained with a single matrix former of type MC, HEC or HPMC, we can observe maximum values of dynamic viscosity of up to 10 Pas for $1 \%$ $2 \%$ cellulose derivatives, an increase to 20 Pas for $3 \% \mathrm{HEC}$, to $30 \mathrm{Pas}$ for $3 \% \mathrm{HPMC}$ and to 40 Pas for $3 \%$ MC hydrogels. For matrix forming agent in concentrations of $4 \%$, there is an increase in viscosity values of up to 30 Pas for HEC and HPMC hydrogels, and surprisingly for the $4 \% \mathrm{MC}$ hydrogel there was a maximum value of about 70 Pas suggesting that hydrophobic interactions between substitutes or substitutes - polymer chain should be considered.

Meantime, in case of the products containing the combinations of cellulose derivatives in concentration of $1 \%$, the registered flow profiles are placed between the profiles of hydrogels prepared with a single matrix former, in $1 \%$ concentration and the flow curves corresponding to industrial products. It can also be noticed the similarity of the Exoderil cream - NHPMC-MC flow profiles.

Analysis of Ostwald de Waele model for naftifine gels

The recorded flow patterns were characterized by three parameters: hysteresis area (difference in area under the share stress $v s$. share rate plot, for the ramp up/ramp down curves, $\mathrm{Pa} / \mathrm{s}$ ); flow index - $\mathrm{n}$ and consistency index - K, calculated according to Ostwald de Waele model:

$$
\tau=\mathrm{K}(\gamma)^{\mathrm{n}}
$$

where: $\tau$ is the share stress $(\mathrm{Pa})$, and $(\gamma)^{\mathrm{n}}$ is the share rate $\left(\mathrm{s}^{-1}\right)$.

The two calculated indices represent the parameters that evaluate the global, not just punctual, the deformation profile under the action of external mechanical stress. For all analysed formulations it was possible to apply the Ostwald de Waele model (indicated by the software used as an optimal approach), and the value of flow index was subunitary, confirming the pseudoplastic character. Calculated values for the consistency index confirm the grouping by range, according to 
the calculated data for hysteresis areas and matrix former concentration. The highly value obtained for the N-HPMC 4\% formulation, over 7000, is masking the distribution by areas according to the concentration of matrix forming agent.

Table II

Equations of the regression lines

\begin{tabular}{|c|c|c|c|}
\hline No. & Formulation & Equation of regression & $\mathbf{R}^{\mathbf{2}}$ \\
\hline $\mathbf{1}$ & N-HEC 1\% & $\mathrm{y}=2.9277^{*} \mathrm{x}^{\wedge} 0.4424$ & 0.9998 \\
\hline $\mathbf{2}$ & N-HEC 2\% & $\mathrm{y}=15.6696^{*} \mathrm{x}^{\wedge} 0.4294$ & 0.9996 \\
\hline $\mathbf{3}$ & N-HEC 3\% & $\mathrm{y}=61.679^{*} \mathrm{x}^{\wedge} 0.3303$ & 0.9998 \\
\hline $\mathbf{4}$ & N-HEC 4\% & $\mathrm{y}=235.8286^{*} \mathrm{x}^{\wedge} 0.0406$ & 0.9999 \\
\hline $\mathbf{5}$ & N-HPMC 1\% & $\mathrm{y}=1.5461^{*} \mathrm{x}^{\wedge} 0.7054$ & 0.9999 \\
\hline $\mathbf{6}$ & N-HPMC 2\% & $\mathrm{y}=18.6648^{*} \mathrm{x}^{\wedge} 0.3577$ & 1.0000 \\
\hline $\mathbf{7}$ & N-HPMC 3\% & $\mathrm{y}=381.1069^{*} \mathrm{x}^{\wedge} 0.009$ & 1.0001 \\
\hline $\mathbf{8}$ & N-HPMC 4\% & $\mathrm{y}=7102.3374^{*} \mathrm{x}^{\wedge} 0.8919$ & 1.0000 \\
\hline $\mathbf{9}$ & N-MC 1\% & $\mathrm{y}=1^{*} \mathrm{x}^{\wedge} 0.7494$ & 0.9995 \\
\hline $\mathbf{1 0}$ & N-MC 2\% & $\mathrm{y}=21.3082^{*} \mathrm{x}^{\wedge} 0.4234$ & 0.9996 \\
\hline $\mathbf{1 1}$ & N-MC 3\% & $\mathrm{y}=164.6203^{*} \mathrm{x}^{\wedge} 0.1731$ & 0.9999 \\
\hline $\mathbf{1 2}$ & N-MC 4\% & $\mathrm{y}=1037.6062^{*} \mathrm{x}^{\wedge} 0.1777$ & 0.9998 \\
\hline $\mathbf{1 3}$ & N-HEC MC & $\mathrm{y}=21.6084^{*} \mathrm{x}^{\wedge} 0.4545$ & 0.9998 \\
\hline $\mathbf{1 4}$ & N-HPMC HEC & $\mathrm{y}=19.8382^{*} \mathrm{x}^{\wedge} 0.3577$ & 0.9997 \\
\hline $\mathbf{1 5}$ & N-HPMC MC & $\mathrm{y}=28.7163^{*} \mathrm{x}^{\wedge} 0.4863$ & 0.9999 \\
\hline $\mathbf{1 6}$ & Exoderil cream & $\mathrm{y}=79.7149 * \mathrm{x}^{\wedge} 0.1914$ & 0.9998 \\
\hline
\end{tabular}
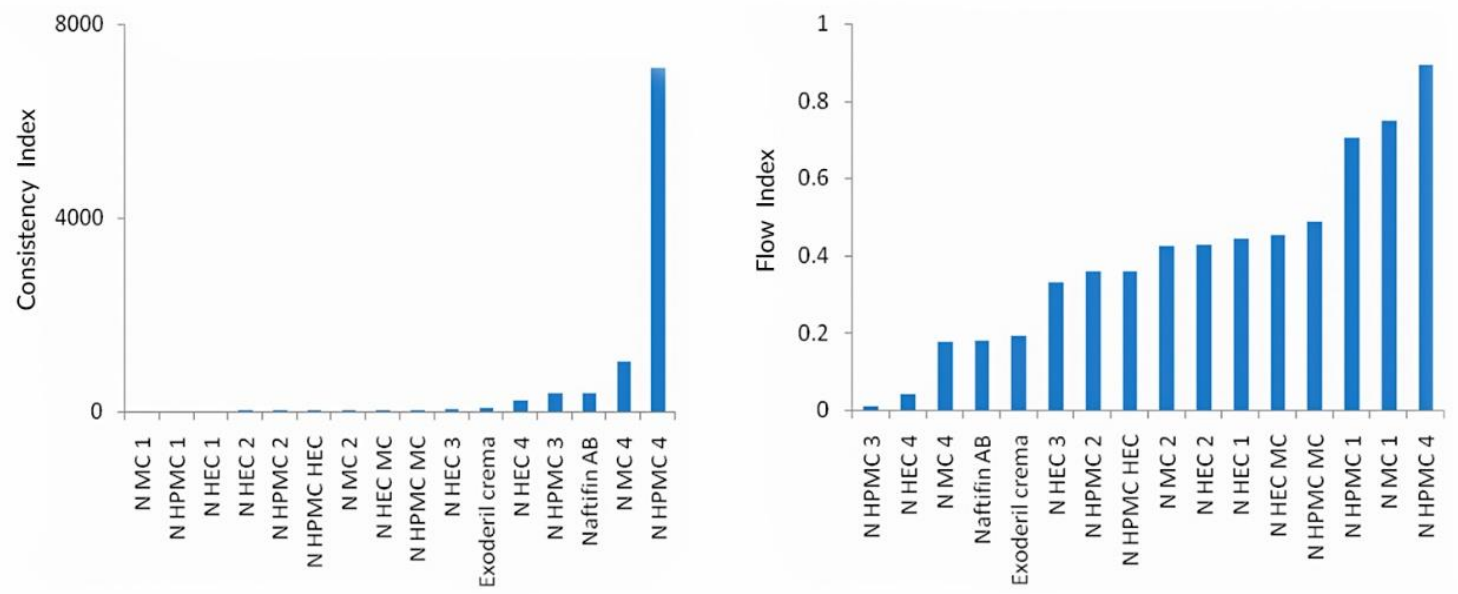

Figure 17.

Variation of consistency and flow indices

\section{In vitro drug release profile}

The range of variation in diffusion coefficient values is extremely small $\left(80-120 \mu \mathrm{g} / \mathrm{cm}^{2} / \mathrm{min}^{1 / 2}\right)$ compared to structural differences that are easily discernible and demonstrated by the analysis of rheological behaviour (Figure 18).

Alternative approaches are possible, one of the simplest being modelling according to an order 1 kinetic. The applicability of the model is depending on a relationship between the transferred quantity (m) per unit of time (t) and the quantity of substance at the level of the donor compartment, as:

$$
\frac{d m}{d t}=-k m
$$

the solution of the equation being:

$$
m(t)=m_{0}\left(1-e^{-k t}\right),
$$

where $m_{0}$ is the initial quantity.
The relation can be written as:

$$
\left(1-\frac{m}{m_{0}}\right)=(1-R / 100)=e^{-k t},
$$

where $\mathrm{R}$ is the percentage of the drug released.

After logarithming it was obtained:

$$
\ln (1-R / 100)=-k t \text {. }
$$

Calculation of the order 1 constant allows the evaluation of the half-life $\left(\mathrm{t}_{1 / 2}=\ln 2 / \mathrm{k}\right)$.

The complex mixture generated by low amounts of ethanol, polyol and surfactant allowed the solubility of naftifine hydrochloride. Active ingredient concentration is close to the maximum solubility allowed by all formulation factors. This characteristic is influencing the general appearance of in vitro release profiles, as the experimental results highlight the dependence on the cellulose derivative concentration, but the relative differences are quite inconsiderable. The 
FARMACIA, 2020, Vol. 68, 6

range of variation in diffusion coefficient values is remarkably low, compared to structural differences
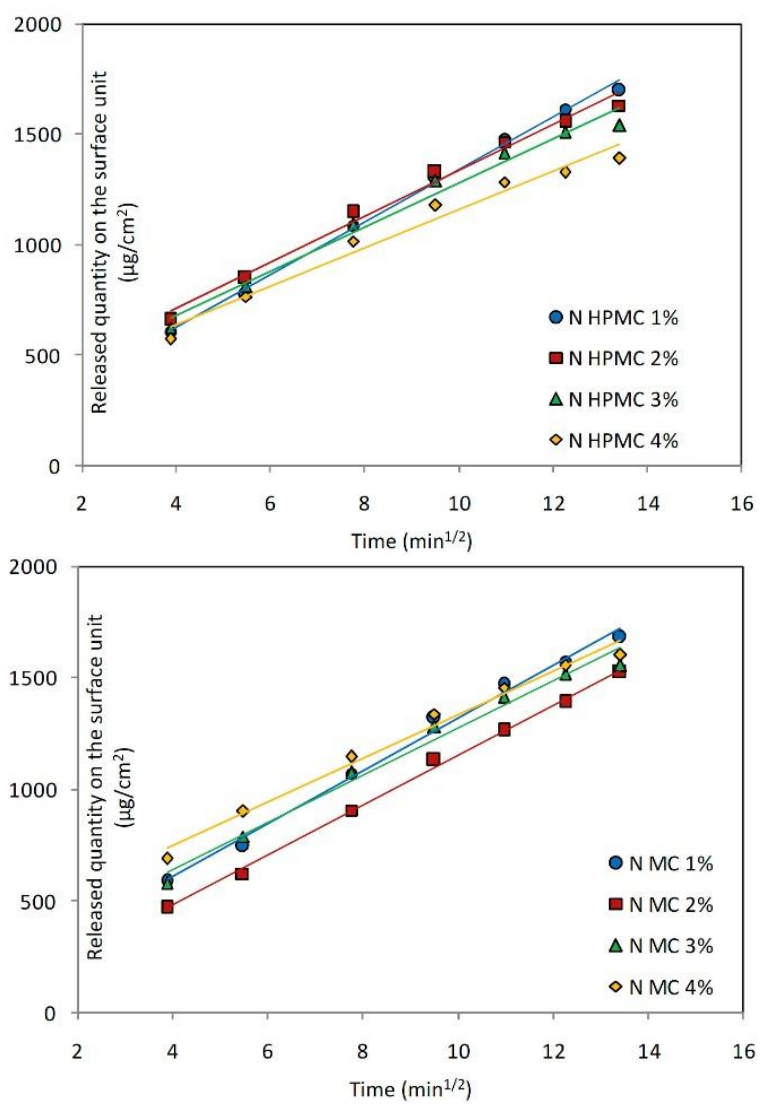

Figure 18.

Release profile of naftifine hydrochloride from cellulose derivative gels

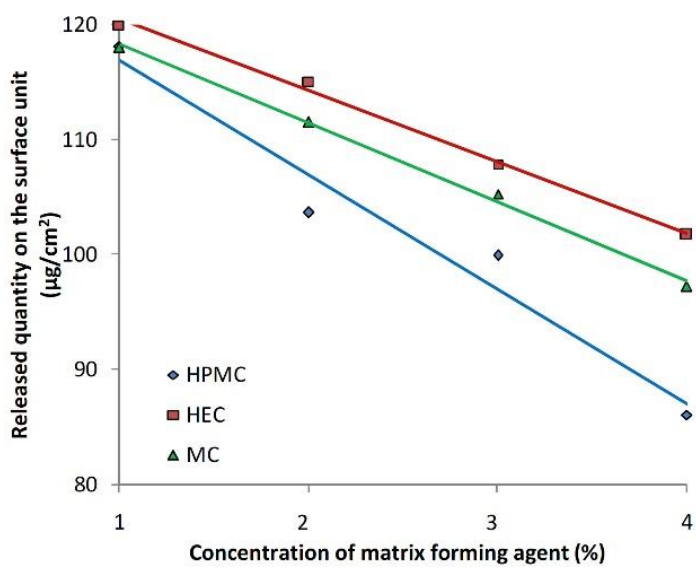

Figure 19.

The influence of matrix forming agent concentration on in vitro release profile

The increase in the concentration of the cellulose derivative matrix former leads to proportional decreases in diffusion coefficient values for naftifine, correlated with structural parameters. Deviation from significant linear dependence (correlation coefficients with values greater than 0.99) are highlighted for HPMC. For intermediate concentrations $(2 \%$ and $3 \%$ ) reduced differences of in vitro release rate have been achieved, probably generated by particular interactions between

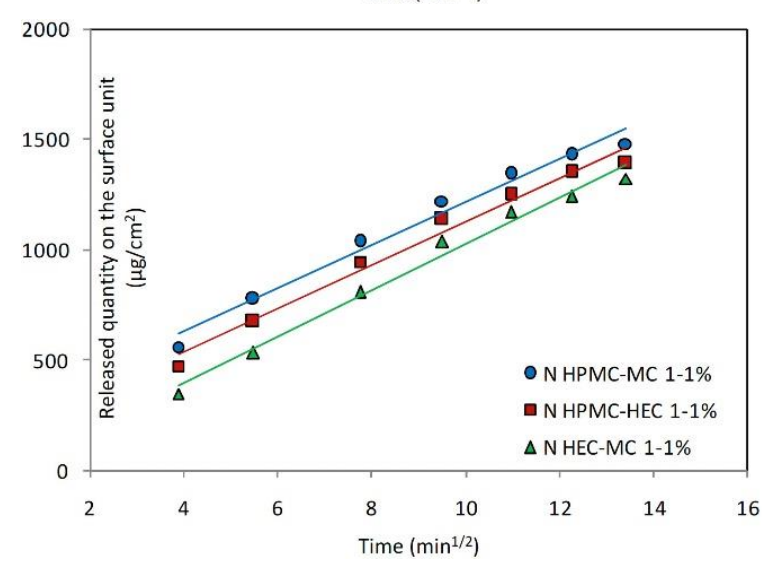

easily detectable and demonstrated by rheological behaviour analysis.

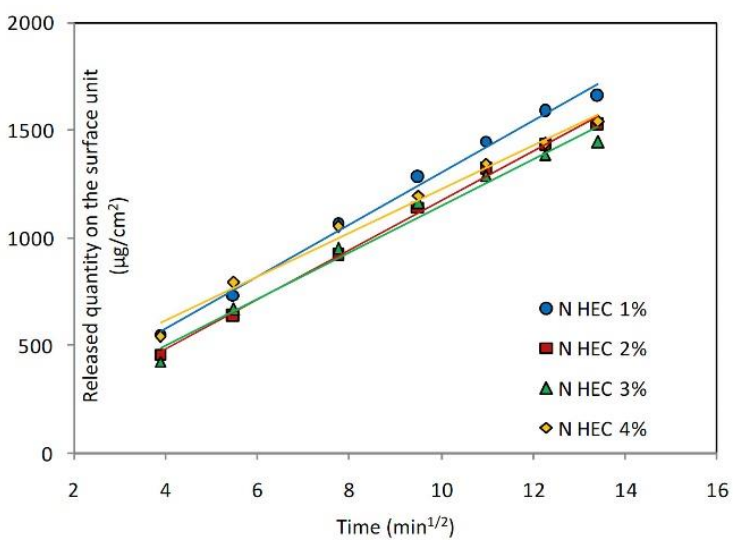
西 
In the present study, four excipients have been selected for their active role in facilitating the transfer through the corneal layer. Isopropanol and propylene glycol are mentioned in the literature as absorption promoters, most likely by altering the corneal layer permeability and by enhancing the solubility of intermediate lipophilic substances.

In vitro release profile modelling

In individual in vitro release profiles obtained for experimental formulations and pharmaceutical products used as references were in accordance with selfimposed acceptance limits. Linearity deviations are experimental evidences of some processes that reduce the predictive value of the in vitro evaluation methodology, including the relevance as a quality control procedure and the inequitable character in relation with structural or compositional differences. Complex mixtures of surfactant compounds lead to a continuous change in the naftifine solubility in the mixture existent at the receiving compartment of the vertical diffusion cell. The release profile is atypical, by increasing the transfer rate to the inert porous membrane interface throughout all the experiment. Isopropanol generates the maximum value of the diffusion coefficient within the group of experimental formulations. The formation of emulsion systems causes the partition between the lipophilic and hydrophilic phases to control the overall diffusion process.

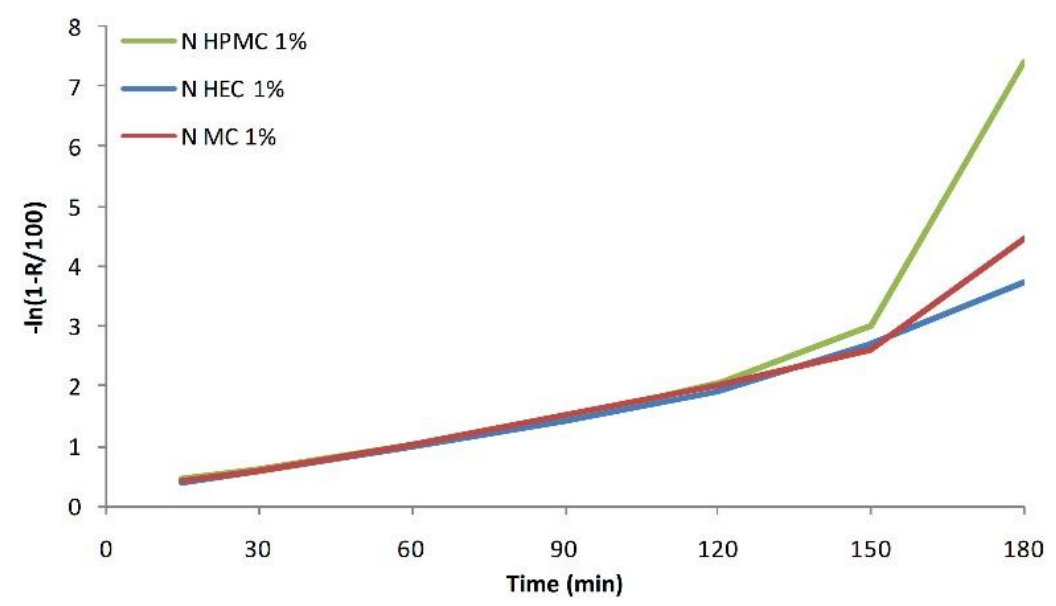

Figure 20.

The release profiles modelling for the formulations containing $1 \%$ cellulose derivative
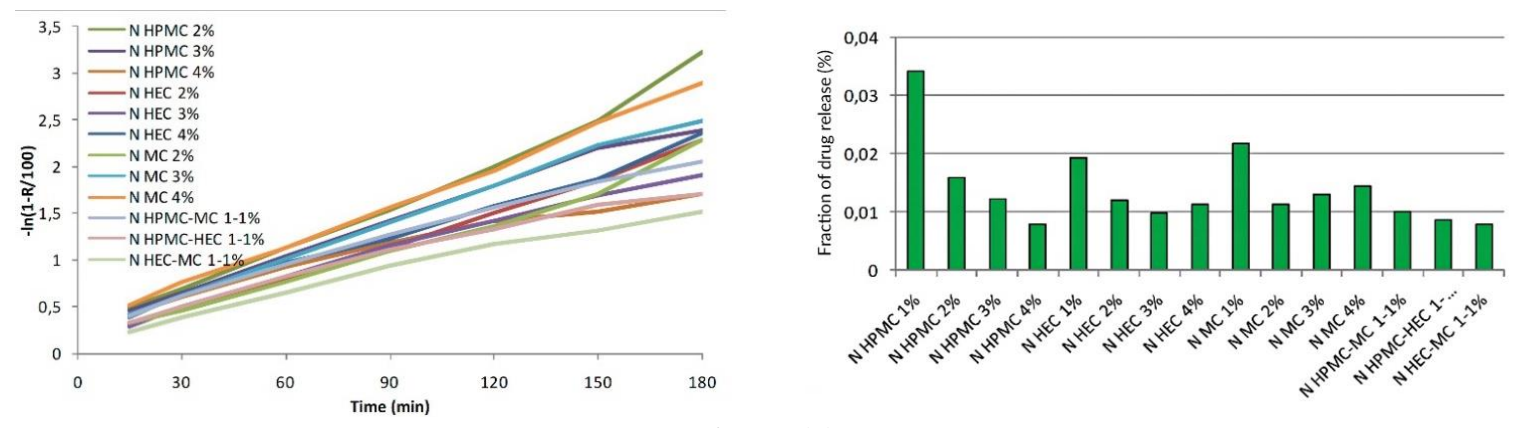

Figure 21.

The release profiles modelling and the transfer constants according to $1^{\text {st }}$ order kinetics

\section{Conclusions}

Fifteen hydrogels formed by different cellulose derivatives containing $1 \%$ naftifine hydrochloride dissolved in a cosolvent mixture containing low amounts of alcoholic components, were formulated, prepared and analysed in the present study.

It has been proven that the major differences of physico-chemical characteristics were the results of the type and concentration of matrix forming agents, as well as of the solubilizing agents used.

Structural deformations induced by mechanical stress had different magnitudes depending on the matrix type generated by compositional factors and processing parameters, assessed by the hysteresis area. The pseudoplastic character was also confirmed by the values of the consistency and flow indices achieved by applying the Ostwald de Waele model.

The increase in the cellulose derivative concentration lead to proportional decreases in diffusion coefficient values for naftifine, related to structural parameters, considering the solubility is on its maximum limit. By correlating, at least from a theoretical point of view, the viscosity and the diffusional resistance, the formulation control of these parameters should be considered an important element in reaching the 
relative similarity to a reference with a wellestablished clinical profile.

\section{Conflict of interest}

The authors declare no conflict of interest.

\section{References}

1. Barakat HS, Darwish IA, El-Khordagui LK, Khalafallah NM, Development of naftifine hydrochloride alcoholfree niosome gel. Drug Dev Ind Pharm., 2009; 35(5): 631-637.

2. Charles PL, Naftifine: A topical antifungal agent reevaluated. J Am Acad Dermatol., 2010; 62: AB85.

3. Gavriloaia MR, Budura EA, Toma CC, Mitu MA, Karampelas O, Arama C, Lupuleasa D, In vitro evaluation of diffusion and rheological profiles for dexamethasone inclusion complexes with $\beta$-cyclodextrin or hydroxypropyl $\beta$-cyclodextrin. Farmacia, 2012; 60(6): 895-904.

4. Mănescu O, Lupuleasa D, Miron DS, Budura EA, Rădulescu FS, In vitro drug release from topical antifungal pharmaceutical formulations. Farmacia, 2011; 59(1): 15-23.

5. Mănescu O, Lupuleasa D, Miron DS, Mitu MA, Golocorbin-Kon S, Rădulescu FS, The influence of structural characteristics on the in vitro drug release rate of naftifine and terbinafine from topical gels. Farmacia, 2012; 60(3): 325-333.

6. Meyerson MS, Scher RK, Hochman LG, Cohen JL, Pappert AS, Holwell JE, Open-label study of the safety and efficacy of naftifine hydrochloride 1 percent gel in patients with distal subungual onychomycosis of the fingers. Cutis, 1993; 51(3): 205-207.

7. Montenegro L, Carbone C, Condorelli G, Drago R, Puglisi G, Effect of oil phase lipophilicity on in vitro drug release from o/w microemulsions with low surfactant content. Drug Dev Ind Pharm., 2006; 32(5): 539-548.

8. Mut AM, Vlaia L, Coneac G, Olariu I, Vlaia V, Popoiu C, Hirjau M, Lupuliasa D, Novel topical chitosan/hydroxyprpylmethylcellulose- based hydrogels containing fluconazole and sucrose esters. Formulation, physicochemical characterization, in vitro drug release and permeation. Farmacia, 2018; 66(1): 59-69.

9. O'Connor NA, Syed A, Wong M, Hicks J, Nunez G, Jitianu A, Siler Z, Polydopamine Antioxidant Hydrogels for Wound Healing Applications. Gels, 2020; 6(4): 1-11.

10. Okada A, Todo H, Hijikuro I, Itakura S, Sugibayashi $\mathrm{K}$, Controlled release of a model hydrophilic high molecular weight compound from injectable nonlamellar liquid crystal formulations containing different types of phospholipids. Int J Pharm., 2020; 577: 118944. doi: 10.1016/j.ijpharm.2019.118944.

11. Olariu I, Coneac G, Hirjau M, Popoiu C, Mut AM, Vlaia V, Sevastre AS, Lupuliasa D, Vlaia L, Evaluation of the barrier potential of some synthetic membranes in testing the in vitro tenoxicam release from hydrogels, using the experimental model with Franz diffusion cells. Farmacia, 2019; 67(1): 73-80.
12. Parida P, Mishra SC, Sahoo S, Behera A, Nayak BP, Development and characterization of ethylcellulose based microsphere for sustained release of nifedipine. J Pharm Anal., 2016; 6: 341-344.

13. Peerapattana J, Hattori Y, Otsuka M, Simultaneous quantitative analysis of indomethacin and benzoic acid in gel using ultra-violet-visible spectrophotometry and chemometrics. Biomed Mater Eng., 2019; 30(1): 73-84.

14. Pershing LK, Bakhtian S, Poncelet CE, Corlett JL, Shah VP, Comparison of skin stripping, in vitro release and skin blanching response methods to measure dose response and similarity of triamcinolone acetonide cream strengths from two manufactured sources. $J$ Pharm Sci., 2002; 91: 1312-1323.

15. Pillay V, Dangor CM, Govender T, Moopanar KR, Ionotropic gelation: encapsulation of indomethacin in calcium alginate gel discs. J Microencapsul., 1998; 15(2): 215-226.

16. Proniuk S, Dixon SE, Blanchard J, Investigation of the utility of an in vitro release test for optimizing semisolid dosage forms. Pharm Dev Technol., 2001; 6(3): 469-476.

17. Shah VP, IV-IVC for topically applied preparationsa critical evaluation. Eur J Pharm Biopharm., 2005; 60(2): 309-314.

18. Siewert M, Dressman J, Brown CK, Shah VP; FIP; AAPS, FIP/AAPS guidelines to dissolution/in vitro release testing of novel/special dosage forms. AAPS PharmSciTech., 2003; 4(1): 43-52.

19. Trombino S, Servidio C, Curcio F, Cassano R, Strategies for hyaluronic acid-based hydrogel design in drug delivery. Pharmaceutics, 2019; 11(8): 1-17.

20. Ubaid M, Ilyas S, Mir S, Khan AK, Rashid R, Khan MZ, Kanwal ZG, Nawaz A, Shah A, Murtaza G, Formulation and in vitro evaluation of carbopol 934based modified clotrimazole gel for topical application. An Acad Bras Cienc., 2016; 88(4): 2303-2317.

21. Ueda CT, Shah VP, Derdzinski K, Ewing G, Flynn GL, Maibach H, Marques M, Rytting H, Shaw S, Thakker K, Yacobi A, Topical and transdermal drug products. Dissolution Technologies, 2010; 17(4): 12-25.

22. Uzqueda M, Martín C, Zornoza A, Sánchez M, Martínez-Ohárriz MC, Vélaz I, Characterization of complexes between naftifine and cyclodextrins in solution and in the solid state. Pharm Res., 2006; 23(5): 980-988.

23. Vulic K, Pakulska MM, Sonthalia R, Ramachandran A, Shoichet MS, Mathematical model accurately predicts protein release from an affinity-based delivery system. J Control Release, 2015; 197: 69-77.

24. Wang NX, von Recum HA, Affinity-based drug delivery. Macromol. Biosci., 2010; 11: 321-332.

25. Zuckerman ST, Rivera-Delgado E, Haley RM, Korley $\mathrm{JN}$, von Recum HA, Elucidating the structure-function relationship of solvent and cross-linker on affinitybased release from cyclodextrin hydrogels. Gels, 2020; 6(1): 1-11. 